\title{
RUOTSIN TIE JA MEIDÄN
}

Jouko Arvonen, Förnyelsens krämpor. Exemplet AMU Stockholms län. University of Stockholm. Department of Psychology. 1991. $162 \mathrm{~s}$.

\begin{abstract}
A mmatillinen aikuiskoulutus on Suomessa ollut kovassa liikkeessä 1980-luvun loppupuolella. Se on noussut työmarkkinaneuvottelujen ja yhteiskuntasopimusten osaksi. Sen kysyntä on kasvanut ja sen rakenteet ja toimintatavat ovat muuttumassa.
\end{abstract}

Ammatillisten kurssikeskusten muuttuminen ammatillisiksi aikuiskoulutuskeskuksiksi on noteerattu tiedotusvälineissäkin.' Muutos sataprosenttisesti valtion rahoin resurssoidusta työllisyyskoulutusorganisaatiosta kohti laaja-alaisia aikuiskoulutusmarkkinoita tavoittelevaksi ja ainakin osittain liiketaloudellisin periaattein toimivaksi palveluorganisaatioksi ei ole helppo. Kun keskeisin koulutuksen tilaaja - työvoimaviranomainen - on samalla saanut oikeuden käyttää muidenkin koulutusorganisaatioiden palveluja, on ammatillisissa aikuiskoulutuskeskuksissa puhuttu henkilöstön lomautuksista kuin yrityksissä ikään.

Onko tällä kehityksellä ulkomaisia esikuvia? Ovatko suomalaiset virkamiehet itse kehittäneet markkinamekanismia jäljittelevän kysyntämallinsa?

Kurssikeskustoimikunnan mietinnössä viitataan Ruotsin, Tanskan ja Saksan liittotasavallan kokemuksiin. Tämän kirjoittajalle ovat opetusministeriön eräät vastuulliset virkamiehet painottaneet, että Ruotsi ei tällä kertaa ole ollut esikuvamme.

K un lukee Jouko Arvosen (1991) tutkimusraI porttia Tukholman aikuiskoulutuskeskuksesta, tulee väistämättä toisiin ajatuksiin. Ruotsin työvoimapoliittisen aikuiskoulutuksen uudistus on yksi yhteen samanlainen kuin meillä markkinoitu kysyntämalliin pohjautuva aikuiskoulutuskeskusten muutos.

Ruotsissa työvoimaviranomaisille on jo 1980-luvun puolivälissä annettu oikeus käyttää tasaveroisesti eri koulutusorganisaatioiden palveluja aikuiskoulutuksessa. Tämä on johtanut perinteisten työllisyyskoulutusorganisaatioiden kannalta — joista käytetään nimeä AMU-center (arbetsmarknadsutbildningscenter) — vähenevään kysyntään.

Oman uudistuksemme kannalta on kuitenkin kiinnostavaa, miten Ruotsin AMU-keskusten toiminta on muuttunut sisäisesti ja ulkoisesti. Arvonen kuvaa perusteellisesti ja monipuolisesti Ruotsin suurimman AMU.-keskuksen (Tukholma) muutosprosessia. Hän on seurannut muu- 
tosta vuodesta 1986 lähtien. Tutkimus on viisivuotisen projektin päätösraportti.

Tukholman AMU-keskuksen muutosstrategia oli yksinkertainen: vähenevän työllisyyskoulutuksen sijaan oli tarkoitus myydä vapaana olevaa koulutuskapasiteettia elinkeinoelämän henkilöstökoulutukseksi ja yksityisille kansalaisille. Pyrittiin siis luomaan kolmet koulutusmarkkinat eli lähestymään eri kohderyhmiä erilaisilla ' koulutustuotteilla".

Kerrottakoon lyhyesti, että tämä strategia epäonnistui lähes täydellisesti. Pyrin seuraavassa tulkitsemaan Arvosen raportin pohjalta, mitkä ovat suomalaisittain kiinnostavimpia epäonnistumisen syitä.

Strategia kolmista markkinoista ei ensinnäkään johtanut organisatorisesti keskuksen sisällä muutokseen: eri markkinoita lähestyttiin siis vanhalla työllisyyskoulutusmarkkinoihin nojautuvalla organisaatiolla. Keskuksen johdon alaisuuteen otettiin kyllä uusia osastonjohtajia elinkeinoelämästä, mutta heidän merkityksensä jäi muutoksessa vähäiseksi.

Keskuksen henkilökunnan osaamistason nostamiseen ei yleisesti ottaen kiinnitetty juuri lainkaan huomioita. Sinänsä luonnollista on, että uudistuksen alkuvaiheessa keskuksen henkilökunta osoitti vastarintaa niin taloudellista kuin sosiaalista muutosta kohtaan. Suomalaisittain kiinnostavaa on se, että osa Tukholman AMUkeskuksen henkilökunnasta näytti aidosti samastuvan perinteiseen koulutettavaryhmäänsä eli yhteiskunnan heikko-osaisiin.

Arvosen mukaan keskuksen johdolla oli myös ' 'kätkettyjä motiiveja'" muutosprosessin taustalla. Johdon pyrkimyksenä oli "lyödä ulos" osa vaikeista työntekijöistä: nämä pyrkimykset ovat ilmeisesti olleet työntekijöidenkin tiedossa.

A rvosen raportti on kertomus ristiriitaisista A tavoitteista, huonosti organisoidusta hallinnosta ja hallitsemattomasta muutoksesta. Ehkä vain ruotsalaisessa yhteiskunnassa on mahdollista, että markkinoilla kilpaileva AMU-keskus ei kysynnän laskiessa voi mennä konkurssiin: ulos lyötiin lopulta vain elinkeinoelämästä otetut osastonjohtajat.

Suomalaisittain tärkeää on pohtia muutoksen johtamista aikuiskoulutusorganisaatiossa. Ammatillisten aikuiskoulutuskeskusten toimintaajatusta ja -tapoja uudistettaessa on ehkä liian vähälle jäänyt henkilöstön aseman ymmärtäminen: vain osaava ja motivoitunut henkilökunta voi aikuiskoulutuksessa tehdä tulosta. Titteleiden tai laskentajärjestelmien muutos ei ole uudistuksen ydin.

$\mathrm{J}$ os olisin ammatillisen aikuiskoulutuskeskuksen johtaja niin pohtisin pitkään myös liian monille markkinoille pyrkimistä: Suomessa monet aikuiskoulutuskeskusten rehtorit ovat olleet innolla luopumassa työvoimapoliittisesta aikuiskoulutuksesta ja suuntautumassa maksukykyisille henkilöstökoulutusmarkkinoille. Kuluneen vuoden aikana on kyllä ollut havaittavissa paluuta toisenlaisiinkin äänenpainoihin: markkinat on helppo menettää mutta uusia ei ole helppo vallata.

Tässä ei oie paneuduttu Arvosen tutkimusraportin tieteellisiin ansioihin tai vajavaisuuksiin. Hän kuvaa tutkimusmetodiaan tapaustutkimukseksi. Tutkija on voinut seurata yhden AMU-keskuksen muutosta sisältä haastattelemalla johtoa ja työntekijöitä sekä osallistumalla monin tavoin keskuksen toimintaan. Tämä johtaa laajaan ja syvälliseen näkökulmaan, mutta aineiston rajauksessa on ongelmia.

Voimme tietenkin pohtia, onko Tukholman AMU-keskuksen suuruus (noin 700 työntekijää, liikevaihto noin 300 miljoonaa kruunua) eräs syy uudistuksen epäonnistumiseen. Arvonen ei paljoakaan hae vertailumateriaalia muista AMUkeskuksista eikä kerro niiden kehityksestä. Toisaalta voi tietenkin kysyä, eikö markkinamekanismiin pohjautuvan aikuiskoulutuksen kysynnän ja tarjonnan pitäisi toimia hyvin juuri suurilla Tukholman tapaisilla markkina-alueilla. Tai voisiko sen sanoa näin: mikä ei siellä menesty, ei ole menestymään tarkoitettukaan.

\section{TAPIO VARMOLA}

